经济, 发展, 景观, 价值

\title{
ECONOMY, DEVELOPMENT, LANDSCAPE AND VALUE
}

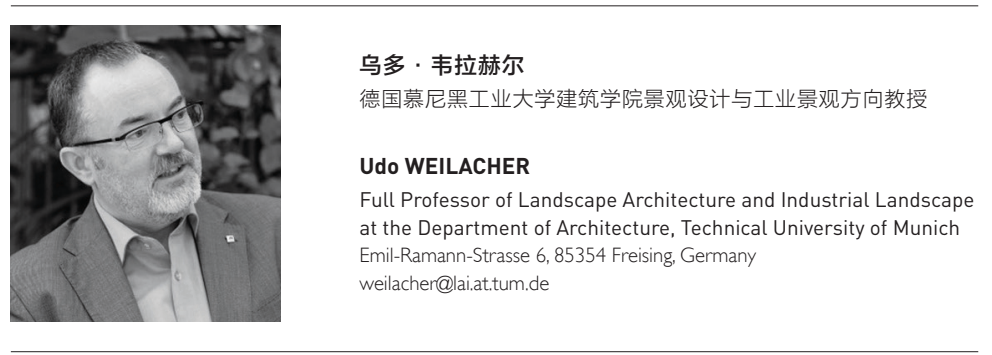

\section{您如何理解景观的经济价值?}

乌多・韦拉赫尔（以下简称韦拉赫 尔）：景观设计师一直都在所谓的 “可持续 性三角” 框架下工作，该框架也被称为“魔 力三角” : 带有多重目标的景观设计项目必 须考虑环境的可持续性, 并以生态、社会和 经济三类指标作为衡量标准。这个框架之所 以被称为 “魔力” 的原因是你无法天真地以 为可以同时在这三个方面都达到百分之百。 但我们可以将这三方面的效益尽可能地扩 大，因此景观设计师必须在这三者之间不断 平衡, 根据既定的规划问题, 以及具体的社 会、生态和经济背景, 为项目设定合理的效 益组合。
景观具有多种经济价值。当然, 每个 人首先想到的都是土地价值。然而, 全球经 济发展的大多数领导力量都低估了景观所拥 有的众多非经济价值, 只将其视为一种有待 开发的资源。有趣的是, 现在越来越多的欧 美投资者或财团开始意识到, 景观为他们的 商业发展提供了非常宝贵的基础 (不限于土 地价值)。例如, 瑞士联邦环境管理办公室 于2012年进行了一项名为 “景观品质作为 选址因素” 的研究, 对于景观在大型公司选 址方面发挥着何种作用进行了调查, 并得出 结论: 对某些行业而言, 景观的品质非常重 要, 部分原因在于好的景观可以为员工提供 优美的工作环境; 而某些公司认为其总部本 身就应该选址于那些景致优美的地方。这些 \begin{tabular}{l|l} 
https://doi.org/10.15302/J-LAF-20180606 & $\begin{array}{l}\text { 采访时间 INTERVIEWED DATE / 2018-11-21 } \\
\text { 中图分类号 / TU986 }\end{array}$
\end{tabular} 文献标识码 / B
摘要

景观具有多种经济价值。然而, 本次采访受访人乌多. 韦拉赫尔指 出, 全球经济发展的大多数领导力量都低估了景观所拥有的众多非经济价 值。他认为, 公众对于景观和环境价值的认知在某种程度上取决于国家的 发展阶段, 并希望发展中国家不要重复发达国家以环境破坏为代价的发 展道路。他继而强调, 尽管景观效益难以进行经济核算, 但景观设计师应 当超越经济计算的语境来讨论景观的环境价值。最后, 韦拉赫尔认为当前 的景观设计学院校教育对景观的经济考量尚不够重视, 但设计必须充满热 情, 才能吸引并感染人们, 这样景观设计师才有机会说服人们为环境改善 而投资。

关键词

景观设计学；经济；价值；发展；教育

\section{ABSTRACT}

Landscape has various economic values. However, Udo Weilacher, the interviewee, argues that most drivers of the global economic development do underestimate the wide range of non-economic values of landscape. He points out that public awareness on the values of landscape and environment somehow depends on the societal developing phase of a country, and hopes that developing countries would not go through the same developments that caused irreversible environmental damage, as what most developed countries did. Weilacher further reflects that the benefits of landscape cannot be economically calculated and landscape architects need to discuss environmental values beyond economic calculation. Finally, he argues that in the current college education of Landscape Architecture, economic aspects of landscape have not been emphasized enough, and landscape design has to be enthusiastic to overwhelm and fascinate people in order to persuade them to invest for environmental improvement.

\section{KEY WORDS}

Landscape Architecture; Economy; Value; Development; Education

采访 余依爽 田乐

整理、译 田乐

INTERVIEWED BY SHE Yishuang Tina TIAN

EDITED AND TRANSLATED BY Tina TIAN 
大公司的商业发展决策者们越来越意识到一 个地区的景观的魅力对于公司商业形象的重 要性, 但在过去, 景观的品质并不会对相关 决策的制定产生如此重大的影响。在这个意 义上, 景观设计学不只是设计花园或公园, 而是在更大的尺度上塑造环境。

\section{您认为公众对于景观和环境价值的认知} 是否在某种程度上取决于国家的发展阶段？

韦拉赫尔：是的，这一点在发达国家 和发展中国家之间存在明显差异。在欧洲的 工业发展阶段（即所谓的“工业革命” 时 期），没有人关心环境问题，因为这些国家 把经济建设视为头等大事; 他们很晚才意识 到人们为了追求经济增长而破坏了自己的生 活基础。当一个人还在为生存而挣扎时, 往 往很少关心环境，也不会注意到其生命支撑 系统处于危险之中。人只有解决了温饱问 题，才可能会察觉到应该对其他一些重要问 题给予更高的关注。我希望发展中国家不要 重复发达国家以造成太多不可扭转的环境破 坏为代价的、不明智的发展道路。

在您看来, 景观设计师如何使公众更好 地意识到他们的设计作品的经济价值?

韦拉赫尔：优质的生活环境可以使居 住在其中的所有人受益。然而, 不可否认的 是, 对景观效益进行经济核算的想法太不切
实际一一比如, 你愿意为清晨的鸟儿唱歌付 多少钱? 又该如何计算呢? 一一尽管我们无 法对景观为人们带来的美好感受和情绪进行 经济评估, 但作为景观设计师, 我们应当超 越经济量化的语境来讨论景观的环境价值。

目前, 景观行业有一种试图通过货币 量化来评估生态系统服务的新趋势。我认为 景观效益在某种程度上可以进行货币化计 算, 但这种方法存在很强的局限性。如果包 括人类在内的生物及自然的价值只能通过经 济指标来评估和评判，那么整个社会的真正 价值就会被忽视，我们的社会和环境品质就 会崩塌，我们的社会行为也会被误导。当 今, 景观设计师经常批判景观被不可持续地 利用、对经济利益的追逐使得我们的生活环 境遭受到严重破坏。然而, 如果我们严格地 遵循这套经济逻辑的话, 我们将陷人一种恶 性循环: 景观设计师将被迫对他们设计中的 每一种品质或禆益进行量化, 为自然标上价 码一一如果我们开始了这个 “游戏” , 即便 不情愿，也得一直 “玩” 下去。

作为一名教育工作者, 您认为当前的景 观设计学院校教育对景观的经济考量是否足 够重视?

韦拉赫尔：我觉得还不够，但可以肯定 的是, 当我们步人社会、接触到实际的项目 委托时, 我们将会自动开始考虑经济因素。 学生应当自由地发挥他们的创造力, 如果我
们在景观设计教学中过早地引人经济限制条 件, 就有可能在一开始扼杀学生的创造力。 我不希望学生出于经济原因而过早妥协他们 的设计。有时候，低年级的学生会问：“我 们应该在设计中考虑经济因素么? 我们的设 计最终会造价过高么? ”而我总是这样回应 他们: “首先, 你的设计必须充满热情, 才 能吸引并感染人们, 这样你才有机会说服 他们投资。”在德国、瑞士等欧洲民主国 家, 人们有权自由地通过投票来选择他们 喜欢的项目。通常情况下, 我们必须尊重 大多数人的选择, 所以景观设计师常需要 非常努力地说服人们对环境改善项目进行投 资。如果我们提出的方案低于人们的预期, 不具备说服力也不鼓舞人心，那么项目将很 难实现或维持下去。

同时, 我们经常为中高年级的学生提 出许多严格的环境、经济、社会等方面的规 划限制, 试图借助这种训练使他们认识到, 这些限制条件有时会有助于激发和释放创造 力。我希望学生们明白, 景观设计学是一门 “戴着镣铐跳舞”的艺术，但我们依然可以 创造出极具价值的生活环境。 LAF 
How do you consider the economic values of landscapes?

\section{Udo WEILACHER (WEILACHER}

hereafter): Landscape architects are permanently working in the so-called "sustainability triangle," also known as a magic triangle: landscape architectural projects, fulfilling diverse purposes, have to contribute to the sustainability of the environment, measured by ecological, social, and economic criteria. The reason why the triangle is called "magic" is that you cannot reach one hundred percent in all of the three aspects. It is a bit naive to believe that you might maximize all three factors. So landscape architects must navigate between these three corner points, allocating the right mix of values to their projects according to the given planning problem, in tune with the respective social, ecological, and economic contexts.

Landscape has various economic values. Everybody first thinks about the land value, of course. However, most drivers of the global economic development do underestimate the wide range of non-economic values of landscape and take it primarily as a resource to be exploited. It is interesting that nowadays more and more American and European investors or economic powers become sensitive to the fact that landscape is providing a very valuable base for their business, not only in terms of land value. In the study "Landscape Quality as a Locational Factor" in 2012, for example, the Swiss Federal Office for the Environment examined what role the landscape plays in the choice of location for major companies and reached the conclusion that for some sectors the quality of the landscape is important, partly so that they can offer employees an attractive residential environment, and in some cases also because the company head office itself should be in a location with an attractive landscape. Business developers are increasingly aware of the importance of the landscape for the attractiveness of a region as a business location, but in the past they were not able to have a significant influence on the corresponding policymaking. Landscape Architecture in this sense is no longer about designing gardens or parks, but about developing cultivated environments at larger scales.

Do you agree that public awareness on the values of landscape and environment somehow depends on the societal developing phase of a country?

WEILACHER: Yes, there are obvious differences between developed and developing countries. In the history of Europe, there was a phase of industrial development, the so-called “industrial revolution," where no one paid attention to environmental issues, because it was more important for the countries to build up their economies. Only very late the people noticed that they destroyed their own basis for life for the sake of economic growth. I think it is understandable that when you are still struggling for survival, you tend to care less about the environment, not noticing that you put your life support system at risk. As soon as you are above the margin of existence and reach a certain comfort level, you might feel that there are other important issues you should better haven taken care of. It would be great if the countries that are still developing would not go through the same stupid developments that the so-called developed countries went through, causing just too much irreversible environmental damage.

In your opinion, how can landscape architects make the economic values of their design better appreciated?

WEILACHER: As humans we are all benefiting from a good quality of 
our living environment. However, it is an undeniable fact that the benefits of landscape cannot be economically calculated ad nauseam. For example, how much money would you pay for a bird singing in the morning? How do we calculate that? It is almost impossible to economically evaluate people's feelings and emotions aroused by a landscape, but it is our responsibility as landscape architects to discuss environmental values beyond economic calculation.

There is a new tendency in our profession that attempts to assess or evaluate ecosystem services by monetary quantification. I do agree that to a certain degree landscape benefits can be calculated monetarily, but only within very strong limits. I am afraid that if the value of living organisms such as humans or nature is only assessed and judged by economic criteria, the true value of a whole society will be overlooked. Our social and environmental quality would collapse, and our social behaviour would be misled. Today landscape architects often criticize that landscape is exploited unsustainably, or our living environment is damaged seriously for economic reasons. However, if we buy into a strict economic logic, we will end up in a vicious circle where landscape architects will be forced to calculate every single quality or benefit of our design, putting a price tag on nature. If we start that "game," we have to play it to the end, no matter whether we want that or not.

As an educator, do you think that the economic aspects of landscape have been emphasized enough in the current college education of Landscape Architecture?

WEILACHER: I am afraid not, but we can be pretty sure that our work will be automatically subject to economic considerations when we go into practice and deal with real clients. Students are encouraged to freely develop their creativity. If we introduce economic limitations of landscape design too early into the education, we will risk to limit students' creativity in the first place. I do not expect students to compromise their design for economic reasons too soon. Sometimes junior students ask questions like "should we take economic factors into consideration, or is our design in the end too expensive?" I always tend to say, "First of all, your design has to be enthusiastic to overwhelm and fascinate people. Then you might have a chance to persuade them to invest." In democratic European countries, such as Germany or Switzerland, people have the freedom and the right to vote for the realization of projects they like. We generally have to respect the public majority, and landscape architects always try very hard to convince people to invest for the improvement of their environment. If we propose plans that are below people's expectations, not persuasive or inspiring, our projects will hardly get realized or well maintained in the long term.

In later phases of landscape design education, we often expose students to many hard planning restrictions, be it environmental, economic, or social. We try to train them to appreciate the fact that sometimes limitations can be very helpful in sparking off and liberating creativity. I expect them to understand that landscape architecture is also an art of working under many restrictions, nevertheless producing valuable living environments. LAF 